\title{
www.czasopisma.pan.pl \\ Effect of Tungsten and Molybdenum on the Crystallization, Microstructure and Properties of Silumin 226
}

\author{
T. Szymczak *, G. Gumienny, T. Pacyniak, K. Walas \\ Department of Materials Engineering and Production Systems, Lodz University of Technology, \\ Stefanowskiego 1/15, 90-924 Łódź, Poland \\ *Corresponding author: e-mail: tomasz.szymczak@p.lodz.pl
}

Received 05.05.2015; accepted in revised form 29.05.2015

\begin{abstract}
The work presents the results of the examinations of silumin 226 as well as a silumin produced on its basis containing a $\mathrm{W}$ and Mo addition introduced in the amount of $0.1 ; 0.2 ; 0.3$ and $0.4 \%$ of both elements simultaneously. Investigations of the crystallization process of the silumins by the TDA method were conducted. Also, a microscopic analysis of their microstructure was performed and their basic mechanical properties were determined. Microstructure tests were made on casts produced in an TDA sampler as well as by the pressure method. The investigations exhibited a change in the course of crystallization of the silumin containing 0.3 and $0.4 \% \mathrm{~W}$ and Mo with respect to silumin 226 and the silumin with the addition of 0.1 and $0.2 \%$. The presence of additional phases which did not occur in the case of lower addition contents was established in the silumin containing $0.3-0.4 \% \mathrm{~W}$ and Mo, regardless of the applied casting technology. The tests showed the possibility of increasing the tensile strength $R_{m}$, the proof stress $R_{p 0,2}$ and the unit elongation $A$ of the silumin as a result of a simultaneous introduction of the $\mathrm{W}$ and Mo addition. The highest values of $\mathrm{R}_{\mathrm{m}}, \mathrm{R}_{\mathrm{p} 0,2}$ and $\mathrm{A}$ were obtained in the silumins with the additions of these elements within the range of $0.1-0.2 \%$ each.
\end{abstract}

Keywords: Theoretical basis of casting processes, pressure casting, multi-component silumins, TDA method

\section{Introduction}

Silumins are alloys characterizing in advantageous mechanical properties, while maintaining a low density, as well as relatively lower production costs, owing to the relatively low melting point. Due to the formation of a disadvantageous coarse-grained microstructure, silumins are rarely cast into sand or ceramic moulds. In the case of these alloys, casting into metal moulds as well as pressure casting are much more frequently applied. In these technologies, due to the use of metal moulds, it is possible to obtain a much more intense heat removal from the casts, which results in the formation of a fine-grained microstructure in them as well as an improvement of their mechanical properties. Beside the intensification of the cooling rate, the improvement of the properties of silumins can be also affected by a change in the chemical composition (introduction of alloy additions or modification), purification (refinement) and thermal treatment [1-3].

Among the many elements introduced into aluminium alloys, the effect of such as $\mathrm{Cr}[4]$ and $\mathrm{V}[5,6]$ has been studied. There is not much data on the effect of $\mathrm{W}$ and Mo on the microstructure and properties of silumins. Because of the lack of solubility in the solid state of these elements in aluminium, they are not used as alloy additions. Due to the very dynamic crystallization of silumin in the pressure mould, there is a possibility to supersaturate the solid solution $\alpha$ both with tungsten and molybdenum. And so, the aim of this work is to examine the effect of $\mathrm{W}$ and Mo on the 
course of the crystallization process, the microstructure and the properties of hypoeutectic silumin casts.

Figure 1 shows the phase equilibrium system Al-W.

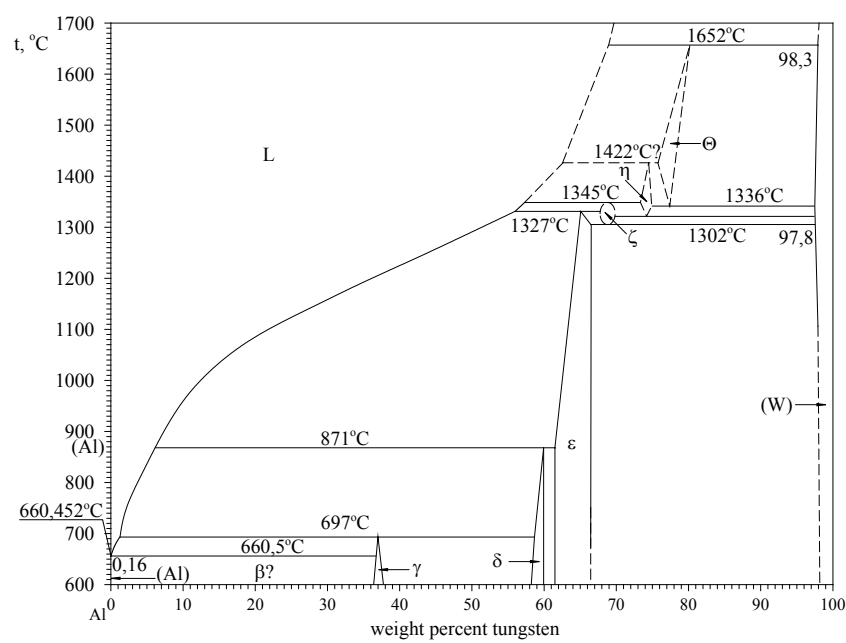

Fig. 1. Phase equilibrium system: aluminium-tungsten [7]

Aluminium forms phases with tungsten, for which the concentration range of $\mathrm{W}$ and the crystallographic parameters are given in Table 1 . The solubility of $\mathrm{W}$ in $\mathrm{Al}$, according to [7], equals $0 \%$ mas, whereas that of $\mathrm{Al}$ in $\mathrm{W}$ equals maximally $2.2 \%$ at the temperature of $1302^{\circ} \mathrm{C}$. Phases $\gamma, \delta$ and $\varepsilon$ are products of the peritectic transformations occurring at the temperatures of: 697, 871 and $1327^{\circ} \mathrm{C}$, respectively.

Table 1.

Types of phases in the Al-W system and their crystallographic parameters [7]

\begin{tabular}{cccc}
\hline Phase & $\begin{array}{l}\text { W concentra- } \\
\text { tion, \% mas. }\end{array}$ & $\begin{array}{c}\text { Pearson } \\
\text { Symbol }\end{array}$ & $\begin{array}{c}\text { Space } \\
\text { group }\end{array}$ \\
\hline$(\mathrm{Al})$ & 0 & $c F 4$ & $F m \overline{3} m$ \\
\hline$\gamma$ & $\sim 37$ & $C i 26$ & $\operatorname{Im} 3$ \\
\hline$\delta$ & $\sim 58-60$ & $h P 12$ & $P 6_{3}$ \\
\hline$\varepsilon$ & $\sim 62-66$ & $m C 30$ & $C m$ \\
\hline $\mathrm{W}$ & 100 & $c I 2$ & $\operatorname{Im} \overline{3} m$ \\
\hline
\end{tabular}

The phase equilibrium system Al-Mo is presented in Figure 2. The data shown in the figure suggests that molybdenum forms a complex phase system, in which the existing phases crystallize as a result of peritectic transformations, except for the $\mathrm{Al}_{8} \mathrm{Mo}_{3}$ phase, which is formed from the liquid at the temperature of $1546^{\circ} \mathrm{C}$ (congruent point with the Mo concentration of about $27.3 \%$ at.). The basic data on the phases existing in the Al-Mo system is presented in Table 2. There is no solubility of Mo in Al, whereas the maximal solubility of $\mathrm{Al}$ in Mo equals $20 \%$ at the temperature of about $2150^{\circ} \mathrm{C}$.

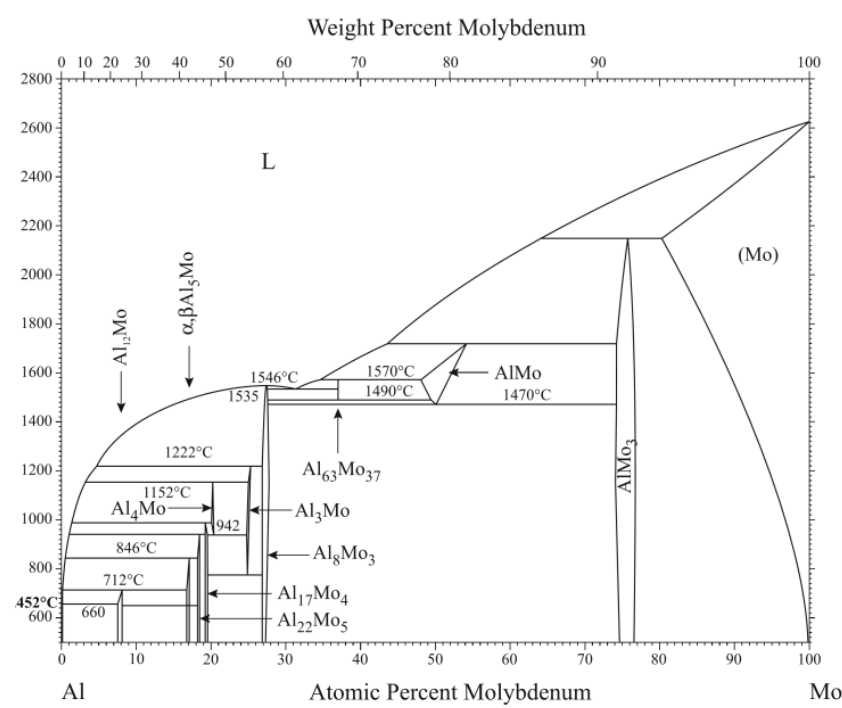

Fig. 2. Phase equilibrium system: aluminium-molybdenum [8]

Table 2.

Types of phases in the Al-Mo system and their crystallographic parameters [8]

\begin{tabular}{cccc}
\hline Phase & $\begin{array}{c}\text { Mo concen- } \\
\text { tration, \% at. }\end{array}$ & $\begin{array}{c}\text { Pearson } \\
\text { Symbol }\end{array}$ & $\begin{array}{c}\text { Space } \\
\text { group }\end{array}$ \\
\hline$(\mathrm{Al})$ & 0 & $c F 4$ & $F m \overline{3} m$ \\
\hline $\mathrm{Al}_{12} \mathrm{Mo}$ & $7.5-8.1$ & $c I 26$ & $\operatorname{Im} \overline{3}$ \\
\hline$\beta \mathrm{Al}_{5} \mathrm{Mo}$ & $16.7-17.1$ & $h P 12$ & $P 6_{3}$ \\
\hline$\alpha \mathrm{Al}_{5} \mathrm{Mo}$ & $16.7-17.1$ & $h R 36$ & $R \overline{3} c$ \\
\hline $\mathrm{Al}_{22} \mathrm{Mo}_{5}$ & $18.2-18.5$ & $o F 216$ & $F d d 2$ \\
\hline $\mathrm{Al}_{17} \mathrm{Mo}_{4}$ & $19-19.3$ & $m C 84$ & $C 2$ \\
\hline $\mathrm{Al}_{4} \mathrm{Mo}$ & $20-20.4$ & $m C 30$ & $C m$ \\
\hline $\mathrm{Al}_{3} \mathrm{Mo}$ & $24.8-25.3$ & $m C 32$ & $C m$ \\
\hline $\mathrm{Al}_{8} \mathrm{Mo}_{3}$ & $26.8-27.8$ & $m C 22$ & $C 2 / m$ \\
\hline $\mathrm{Al}_{63} \mathrm{Mo}_{37}$ & 37 & $\ldots$ & $\ldots$ \\
\hline $\mathrm{AlMo}$ & $48.1-54.1$ & $c I 2$ & $\operatorname{Im} \overline{3} m$ \\
\hline $\mathrm{AlMo}_{3}$ & $74.2-76.6$ & $c P 8$ & $P m \overline{3} n$ \\
\hline$(\mathrm{Mo})$ & $80-100$ & $c I 2$ & $\operatorname{Im} \overline{3} m$ \\
\hline
\end{tabular}

\section{Test methodology}

The tests were performed with the use of 'pure' silumin 226 as well as silumins produced on its basis with a simultaneous addition of $\mathrm{W}$ and Mo in the amount of about: $0.1 ; 0.2 ; 0.3$ and $0.4 \%$ of each element. The chemical composition of silumin 226 used in the tests is presented in Table 3.

Table 3.

Chemical composition of silumin 226 used for the tests

\begin{tabular}{cccccccc}
\hline \multicolumn{7}{c}{ Chemical composition, \% } \\
\hline $\mathrm{Si}$ & $\mathrm{Cu}$ & $\mathrm{Zn}$ & $\mathrm{Fe}$ & $\mathrm{Mg}$ & $\mathrm{Mn}$ & $\mathrm{Ni}$ & $\mathrm{Al}$ \\
\hline 9.19 & 2.09 & 0.90 & 0.92 & 0.26 & 0.23 & 0.10 & residue \\
\hline
\end{tabular}

The base silumin was melted in a gas heated shaft furnace with the capacity of 1.5 ton, inside which it underwent refinement 
by means of the solid refiner Ecosal Al 113.S. After it had been lowered into the ladle, the silumin was deslagged and transported to a holding furnace, into which the master alloys AlW8 and AlMo8 had been introduced, which allowed obtaining the assumed concentration of $\mathrm{W}$ and Mo in the silumin. The obtained alloy was used to make casts of a roller blind casing cap. The dominating thickness of the cast's wall equaled $2 \mathrm{~mm}$. The casts were made on a pressure casting machine with the horizontal cold pressure chamber Idra $700 \mathrm{~S}$. The processes of both the liquid silumin's preparation and of the production of pressure casts for the tests were conducted under the production conditions of the Innovation and Implementation Enterprise Wifama-Prexer Ltd.. For each tested chemical composition of the silumin, the process of crystallization was also investigated with the TDA method. The thermal and derivational analysis is a universal method of examining the crystallization process of metal alloys. So far, it has been applied in the tests on alloys of such metals as: iron, aluminum, bronze, magnesium and cobalt [9-12].

To record the TDA curves of the silumin, the thermocouple PtRh10-Pt was used, placed in the TDA10-PE tester made of coated sand. Before it was poured into the tester, the silumin was heated to the temperature of $1100^{\circ} \mathrm{C}$.

In order to perform strength tests, 3 samples were cut out of the cap casts, which had the rectangular section of $2 / 10 \mathrm{~mm}$. This is the section recommended by the standard for strength tests of pressure casts [13]. The tensile tests were conducted on the testing machine Instron 3382. The applied tension rate was $1 \mathrm{~mm} / \mathrm{min}$. In the tensile test, the following parameters were determined: tensile strength $\mathrm{R}_{\mathrm{m}}$, proof stress $\mathrm{R}_{\mathrm{p} 0,2}$ and unit elongation A.

The hardness tests were performed on samples taken from the casts made in the TDA sampler, as well as from the pressure casts. The microsections were etched with a $2 \%$ water solution $\mathrm{HF}$ and observed with the magnification resulting from the size of the microstructure elements obtained in the particular cast groups. For the casts made in the TDA sampler, the magnification was $\times 100$, whereas in the case of the pressure casts, the applied magnification was $\times 1000$. The microstructure of the casts was examined on the metallographic microscope Eclipse MA200 by Nikon.

\section{Test results}

Figure 3 shows the TDA curves of silumin 226. The crystallization process of the silumin begins with the formation of dendrites of phase $\alpha$. On the derivation curve, the thermal effect of this process is denoted with the points PkAB. Another thermal effect, denoted as $\mathrm{BEH}$, is responsible for the crystallization of a ternary eutectic $\left(\alpha+\mathrm{Al}_{9} \mathrm{Fe}_{3} \mathrm{Si}_{2}+\beta\right)$. From the last portions of the liquid silumin, a quaternary eutectic crystallizes $\left(\alpha+\mathrm{Al}_{2} \mathrm{Cu}+\right.$ $\mathrm{AlSiFeCuMgMnNi}+\beta$ ). This effect is denoted by the points HKL. For the silumins containing about 0.1 and $0.2 \%$ of both W and Mo, analogical affects were obtained on the TDA curves. It can be supposed that, with the lack of additional thermal effects on the curves and the lack of solubility of W and Mo in phase $\alpha$, these elements can exist in the most complex phase of the quaternary eutectic, which, after the introduction of the $\mathrm{W}$ and Mo additions, should have the form $\alpha+\mathrm{Al}_{2} \mathrm{Cu}+\mathrm{AlSiFeCuMgMn}-$ $\mathrm{NiWMo}+\beta$. Differences were also present in the coordinates of the characteristic points marked on the TDA curves. A compilation of the temperatures and the cooling rates in the characteristic points for the base silumin and the one containing about $0.1 \div 0.4 \%$ of both $\mathrm{W}$ and Mo is presented in Table $4(\mathrm{a}, \mathrm{b})$. For the silumins containing the $\mathrm{W}$ and Mo addition in the amount of about $0.2 \%$, the temperature differences in the particular points do not exceed $4^{\circ} \mathrm{C}$.

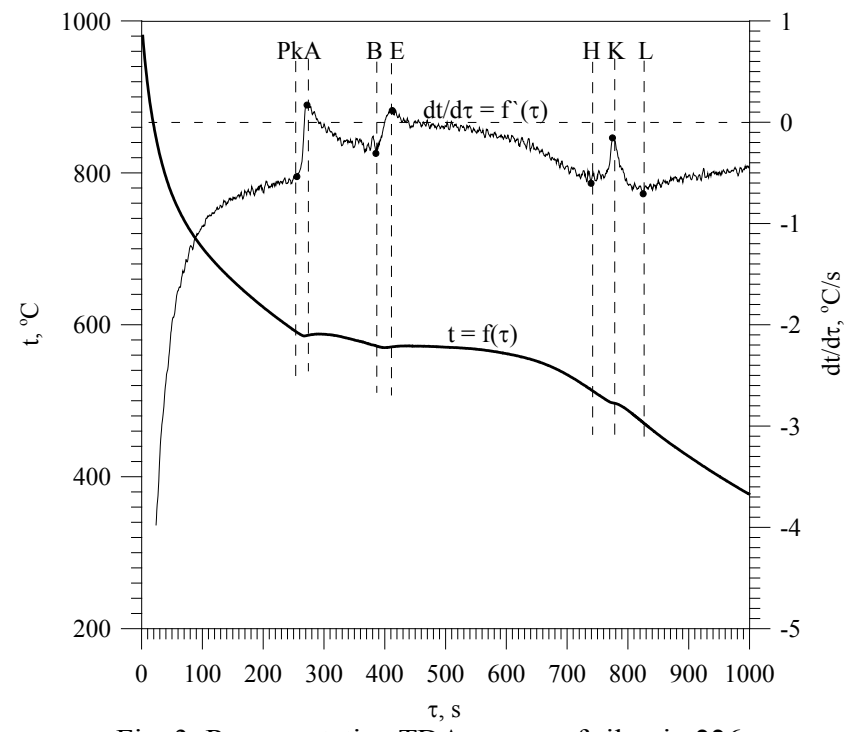

Fig. 3. Representative TDA curves of silumin 226

Table $4(a, b)$.

Compilation of the values of temperature (a) and cooling rate (b) in characteristic points for silumin 226 and silumin with $0,1 \div 0,4 \%$ addition of $\mathrm{W}$ and $\mathrm{Mo}$

\begin{tabular}{|c|c|c|c|c|c|c|c|c|}
\hline \multirow{2}{*}{$\begin{array}{c}\mathrm{W} \text { and } \\
\text { Mo } \\
\text { addition, } \\
\% \\
\end{array}$} & \multicolumn{8}{|c|}{ Temperature $\mathrm{t},{ }^{\circ} \mathrm{C}$} \\
\hline & $\mathrm{Pk}$ & $A^{\prime}$ & A & B & E & $\mathrm{H}$ & $\mathrm{K}$ & $\mathrm{L}$ \\
\hline 0.0 & 590 & - & 586 & 572 & 571 & 514 & 496 & 471 \\
\hline 0.1 & 588 & - & 585 & 572 & 572 & 515 & 497 & 475 \\
\hline 0.2 & 590 & - & 587 & 575 & 573 & 518 & 498 & 473 \\
\hline 0.3 & 634 & 589 & 585 & 574 & 572 & 517 & 498 & 477 \\
\hline 0.4 & 640 & 589 & 584 & 572 & 570 & 512 & 495 & 472 \\
\hline \multicolumn{9}{|l|}{ b) } \\
\hline \multirow{2}{*}{$\begin{array}{c}\mathrm{W} \text { and } \\
\text { Mo } \\
\text { addition, } \\
\% \\
\end{array}$} & \multicolumn{8}{|c|}{$\mathrm{dt} / \mathrm{d} \tau,{ }^{\circ} \mathrm{C} / \mathrm{s}$} \\
\hline & $\mathrm{Pk}$ & $A^{\prime}$ & A & B & E & $\mathrm{H}$ & $\mathrm{K}$ & $\mathrm{L}$ \\
\hline 0.0 & -0.54 & - & 0.17 & -0.31 & 0.12 & -0.60 & -0.15 & -0.71 \\
\hline 0.1 & -0.52 & - & 0.13 & -0.20 & 0.13 & -0.58 & -0.13 & -0.70 \\
\hline 0.2 & -0.55 & - & 0.09 & -0.25 & 0.11 & -0.54 & -0.10 & -0.68 \\
\hline 0.3 & -0.78 & -0.51 & 0.15 & -0.20 & 0.05 & -0.57 & -0.16 & -0.72 \\
\hline 0.4 & -0.80 & -0.53 & 0.09 & -0.24 & 0.05 & -0.55 & -0.19 & -0.62 \\
\hline
\end{tabular}


Introducing the $\mathrm{W}$ and $\mathrm{Mo}$ addition of about 0,3 and $0,4 \%$ caused the occurrence of an additional thermal effect in respect of the silumin without an addition and the silumin with the addition of up to $0.2 \%$ of $\mathrm{W}$ and Mo, on the derivation curve. Figure 4 shows exemplary TDA curves of the silumin containing about $0.4 \%$ of both $\mathrm{W}$ and Mo, on which an additional thermal effect occurs. This effect, denoted as PkA', precedes the effect from the crystallization of phase $\alpha\left(\mathrm{A}^{\prime} \mathrm{AB}\right)$ and two more effects originating from the crystallization of the ternary $(\mathrm{BEH})$ and quaternary (HKL) eutectic. The PkA' effect was probably caused by the crystallization of the phase containing $\mathrm{W}$ and Mo.

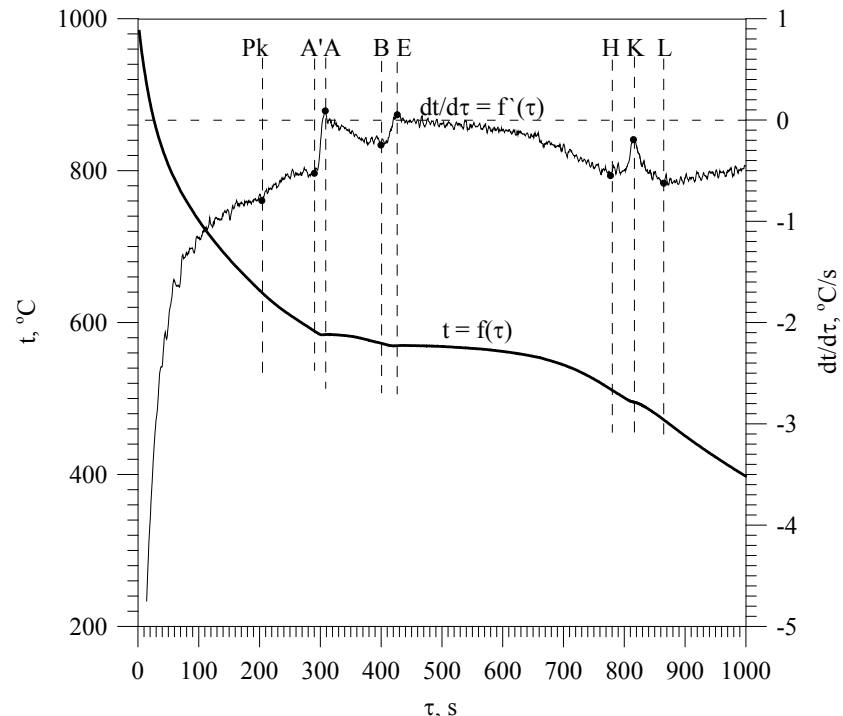

Fig. 4. Representative TDA curves of silumin with $0.4 \% \mathrm{~W}$ and Mo addition

The data in Tab. 4a suggests that the crystallization of the phase to which the PkA' effect corresponds on the TDA curves, causes a significant increase of the temperature of the beginning of crystallization , $t_{\mathrm{Pk}}$ " of the silumin. For the silumins without the addition and with the addition of $\mathrm{W}$ and Mo of up to $0.2 \%$, the temperature in point "Pk" is within the range of $588 \div 590^{\circ} \mathrm{C}$, whereas, after the introduction of 0.3 and $0.4 \%$ of these additions, it assumes values from the range $t_{P k}=634 \div 640^{\circ} \mathrm{C}$. The temperature difference in the remaining characteristic points on the TDA curves of the examined silumins does not exceed $6^{\circ} \mathrm{C}$, regardless of the concentration of $\mathrm{W}$ and Mo. The effect of both elements on the temperature of the beginning and end of the transformations as well as the cooling rate in the particular characteristic points is not explicit (Tab. $4(a, b))$.

Figure 5 shows the microstructure of silumin 226 obtained in the cast made in the TDA sampler.

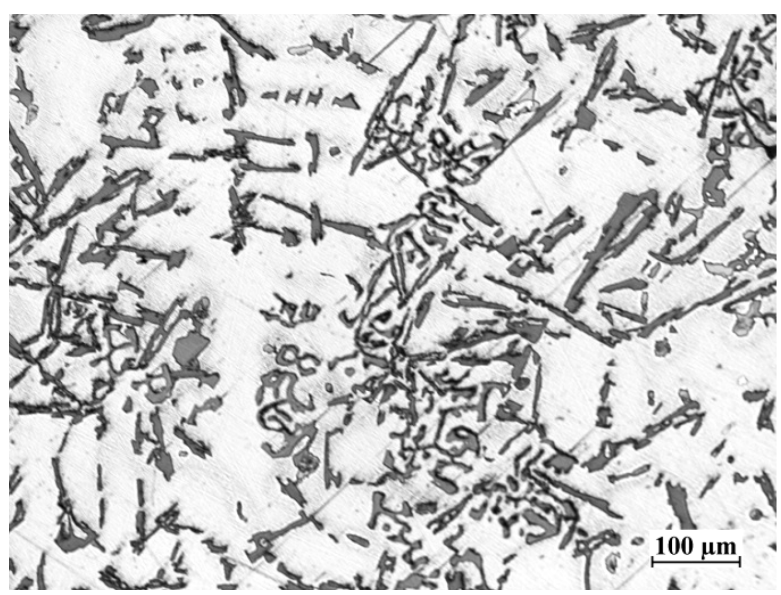

Fig. 5. Microstructure of silumin 226 obtained in the cast made in the TDA sampler: $\alpha, \alpha+\mathrm{Al}_{9} \mathrm{Fe}_{3} \mathrm{Si}_{2}+\beta$, $\alpha+\mathrm{Al}_{2} \mathrm{Cu}+\mathrm{AlSiCuFeMgMnNi}+\beta$

The microstructure presented in Fig. 5 is in accordance with the crystallization process of silumin 226 recorded on the TDA curves, which was described above. It consists of dendrites of the solid solution $\alpha(\mathrm{Al})$, primary crystallizing from the liquid, the ternary eutectic $\alpha+\mathrm{Al}_{9} \mathrm{Fe}_{3} \mathrm{Si}_{2}+\beta$ and the quaternary eutectic $\alpha+\mathrm{Al}_{2} \mathrm{Cu}+\mathrm{AlSiCuFeMgMnNi}+\beta$. In the microstructure of the silumin containing 0.1 and $0.2 \%$ of both $\mathrm{W}$ and Mo, phase $\alpha$ and the ternary eutectic $\alpha+\mathrm{Al}_{9} \mathrm{Fe}_{3} \mathrm{Si}_{2}+\beta$ exist in a similar form, as was the case of the base silumin 226. In the most complex phase of the quaternary eutectic, crystallizing from the liquid residue, atoms of $\mathrm{W}$ and Mo are probably present. In the silumins with the 0.1 and $0.2 \%$ addition of $\mathrm{W}$ and $\mathrm{Mo}$, this phase will have the form Al$\mathrm{SiCuFeMgMnNiWMo.} \mathrm{A} \mathrm{clear} \mathrm{change} \mathrm{in} \mathrm{the} \mathrm{microstructure} \mathrm{of}$ the examined silumin takes place after the introduction of $\mathrm{W}$ and Mo in the amount of 0.3 and $0.4 \%$. As an example, Figure 6 shows the microstructure of the silumin with the addition of about $0.3 \%$ of both $\mathrm{W}$ and Mo obtained in the TDA sampler.

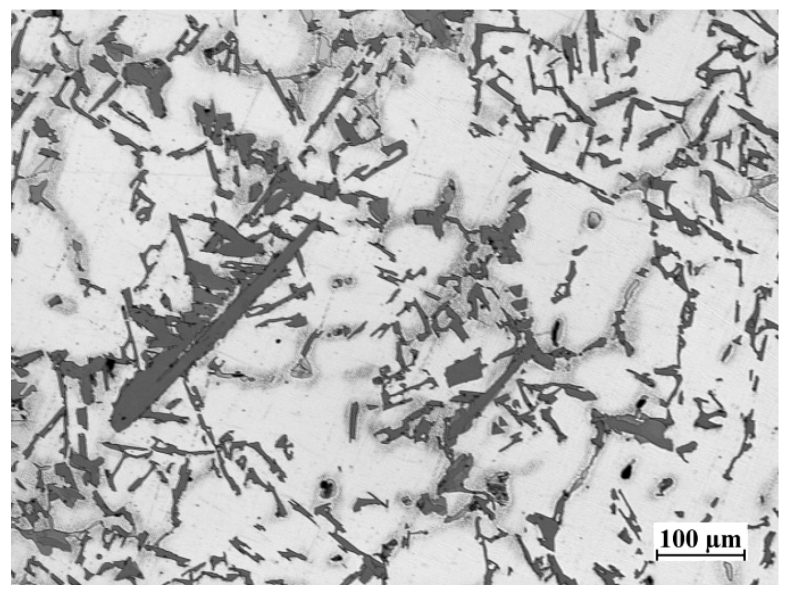

Fig. 6. Microstructure of the cast from the TDA sampler made of the examined silumin with the addition of $0.3 \% \mathrm{~W}$ and $\mathrm{Mo}: \alpha, \alpha+$ $\mathrm{Al}_{9} \mathrm{Fe}_{3} \mathrm{Si}_{2}+\beta, \alpha+\mathrm{Al}_{2} \mathrm{Cu}+\mathrm{AlSiCuFeMgMnNiW}+\beta$

The data presented in Fig. 6 suggests the presence, in the silumin with the $0.3 \% \mathrm{~W}$ and Mo addition, of a phase which does 
not exist in the 'pure' silumin 226 or the silumins containing up to $0.2 \% \mathrm{~W}$ and Mo. This phase was also present in the microstructure of the silumin containing $0.4 \%$ of $\mathrm{W}$ and Mo. Silumin 226, crystallizing in the pressure mould, has an analogous phase composition to that of the silumin crystallizing in the TDA sampler. The microstructure of silumin 226 obtained in the pressure cast is shown in Figure 7.

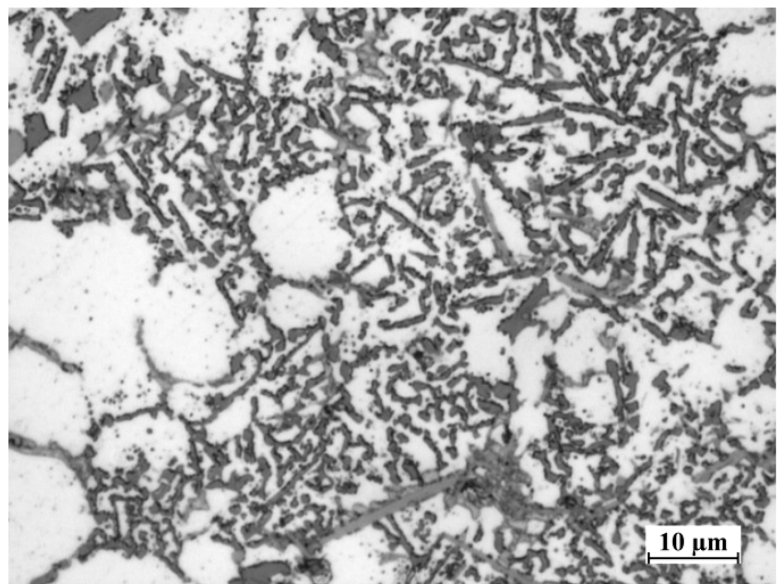

Fig. 7. Microstructure of silumin 226 obtained in the pressure cast: $\alpha, \alpha+\mathrm{Al}_{9} \mathrm{Fe}_{3} \mathrm{Si}_{2}+\beta, \alpha+\mathrm{Al}_{2} \mathrm{Cu}+\mathrm{AlSiCuFeMgMnNi}+\beta$

The data presented in Fig. 7 suggests a significant refinement of the microstructure of the pressure cast and a smaller amount of precipitations of intermetallic phases than in the case of the TDA sampler cast. Both changes are caused by the very intense heat reception from the cast by the pressure mould. The high rate of the heat removal leads to a non-uniform course of the alloy's crystallization and, in consequence, to oversaturation of the solid solution $\alpha$ with the alloy additions. Analogically to the silumin cast in the TDA sampler, a clear change in microstructure of the pressure cast silumin occurred after the introduction of the $0,3 \%$ addition of $\mathrm{W}$ and Mo. The microstructure of the pressure cast with the addition of $0.3 \% \mathrm{~W}$ and Mo is presented in Figure 8 .

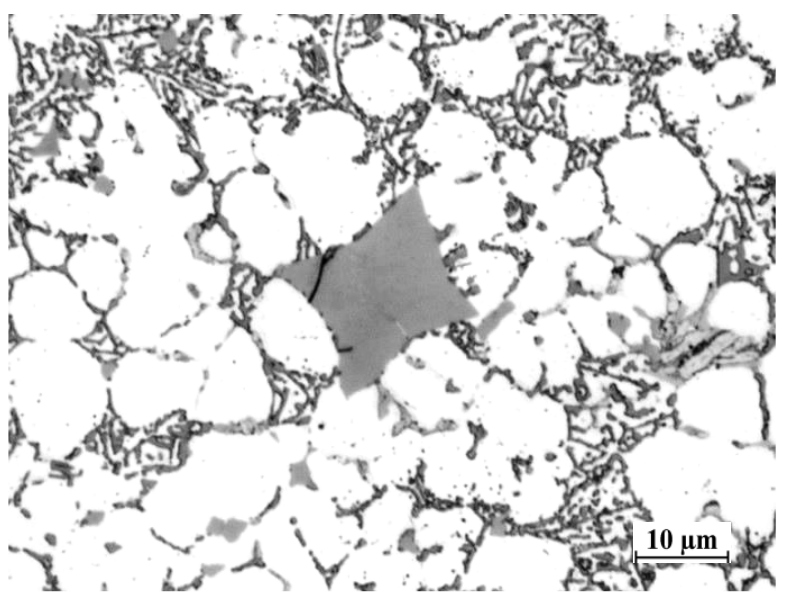

Fig. 8. Microstructure of the pressure cast made of the examined silumin with the $0.3 \% \mathrm{~W}$ and Mo addition: $\alpha, \alpha+\mathrm{Al}_{9} \mathrm{Fe}_{3} \mathrm{Si}_{2}+\beta, \alpha$ $+\mathrm{Al}_{2} \mathrm{Cu}+\mathrm{AlSiCuFeMgMnNiWMo}+\beta$
The microstructure shown in Fig. 8 suggests the occurrence, in the examined silumin with the $0.3 \% \mathrm{~W}$ and Mo addition, of a phase which did not exist in the case of the lower tested contents of these additions. These phases also occurred in the silumin with the addition of about $0.4 \% \mathrm{~W}$ and Mo.

Table 5 and Figure $9(a \div \mathrm{c})$ show the tests results of the basic mechanical properties of the base silumin and the silumin with the $0.1 \div 0.4 \% \mathrm{~W}$ and Mo addition.

Table 5.

Mechanical properties of silumin with and without $\mathrm{W}$ and Mo

\begin{tabular}{ccccc} 
W and Mo & \multicolumn{4}{c}{ Mechanical properties } \\
\cline { 2 - 5 } addition, \% & $\begin{array}{c}\mathrm{R}_{\mathrm{m},}, \\
\mathrm{MPa}\end{array}$ & $\begin{array}{c}\mathrm{R}_{\mathrm{p} 0,2,} \\
\mathrm{MPa}\end{array}$ & $\begin{array}{c}\mathrm{A}, \\
\%\end{array}$ & $\mathrm{HB}$ \\
\hline 0.0 & 251 & 120 & 3.7 & 116 \\
\hline 0.1 & 257 & 127 & 3.5 & 112 \\
\hline 0.2 & 267 & 122 & 4.7 & 108 \\
\hline 0.3 & 217 & 112 & 3.0 & 112 \\
\hline 0.4 & 240 & 112 & 3.8 & 110 \\
\hline
\end{tabular}

a)

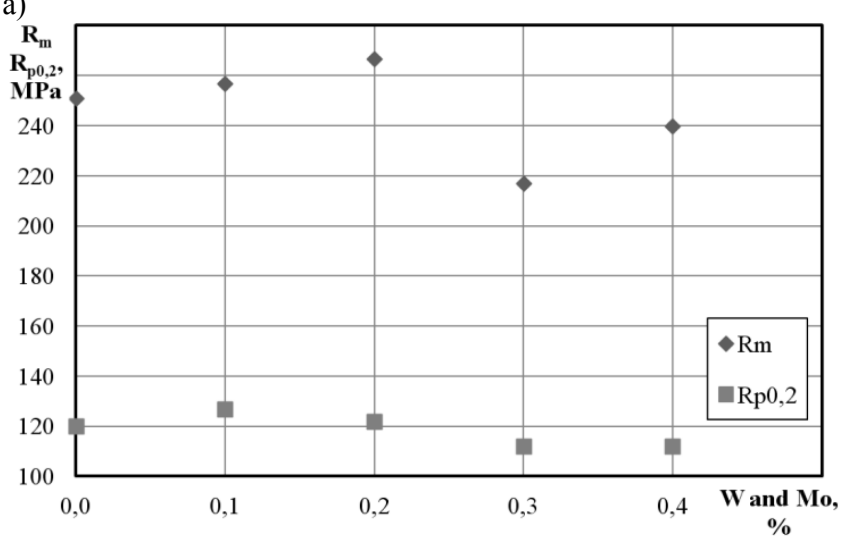

b)

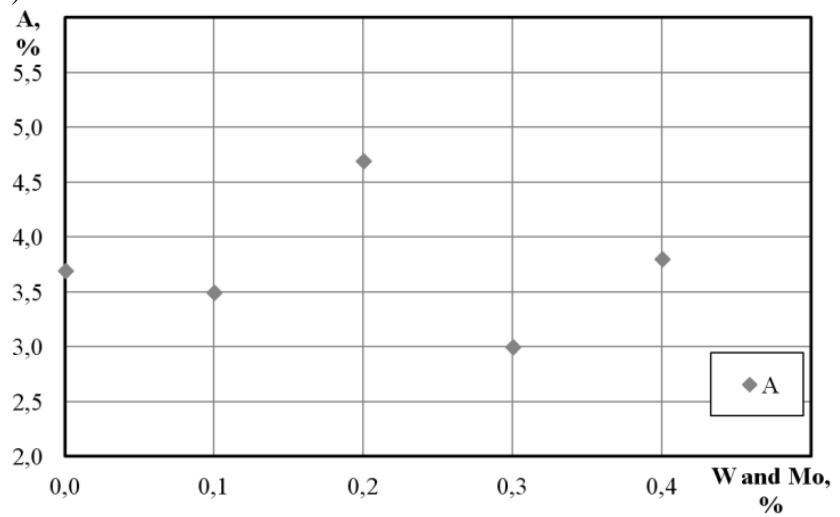


c)

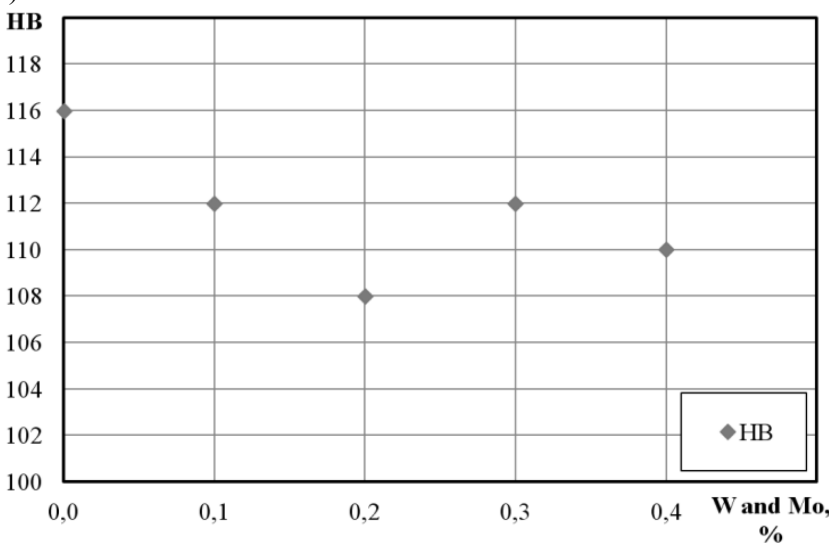

Fig. $9(\mathrm{a} \div \mathrm{c})$. Mechanical properties of silumin 226 with and without $\mathrm{W}$ and Mo

The presented data suggests that silumin 226 characterizes in the tensile strength $R_{m}=251 \mathrm{MPa}$; the proof stress $R_{p 0,2}=120 \mathrm{MPa}$; the unit elongation $\mathrm{A}=3.7 \%$ and the hardness $116 \mathrm{HB}$. Introducing $\mathrm{W}$ and Mo can cause an increase of $\mathrm{R}_{\mathrm{m}}, \mathrm{R}_{\mathrm{p} 0,2}$ and $\mathrm{A}$. The highest values, $R_{m}=267 \mathrm{MPa}$ and $A=4,7 \%$, were obtained for the silumin containing the $0.2 \% \mathrm{~W}$ and Mo addition. This gives an increase of $\mathrm{R}_{\mathrm{m}}$ by $6.4 \%$ and of $\mathrm{A}$ by $27 \%$ in the relative aspect. The highest value, $\mathrm{R}_{\mathrm{p} 0,2}=127 \mathrm{MPa}$, was obtained after the introduction of $0.1 \% \mathrm{~W}$ and Mo into the silumin, which constitutes a $5.8 \%$ increase. For all the applied amounts of the $\mathrm{W}$ and Mo addition, a decrease of hardness HB was obtained.

\section{Conclusions}

The data presented in the paper makes it possible to draw the following conclusions:

- $\quad$ on the TDA curves of the silumin without an addition as well as with the addition of 0,1 and $0.2 \% \mathrm{~W}$ and $\mathrm{Mo}$, one can observe three thermal effects originating from the crystallization of: phase $\alpha(\mathrm{Al})$, a ternary eutectic and a quaternary eutectic,

- on the TDA curves of the silumin with the addition of 0.3 and $0.4 \% \mathrm{~W}$ and Mo, one can observe an additional thermal effect, which probably originates from the crystallization of the phase containing these elements,

- in the microstructure of the silumin with the addition of 0.3 and $0.4 \% \mathrm{~W}$ and $\mathrm{Mo}$, regardless of the applied casting technology, one can observe phases whose presence was not stated in the pure silumin or in the one with the addition of 0.1 and $0.2 \% \mathrm{~W}$ and $\mathrm{Mo}$,

- the highest values of tensile strength $\mathrm{R}_{\mathrm{m}}=267 \mathrm{MPa}$ and unit elongation $\mathrm{A}=4.7 \%$ were obtained for the addition of $0.2 \%$ $\mathrm{W}$ and $\mathrm{Mo}$, and of yield stress $\mathrm{R}_{\mathrm{p} 0,2}=127 \mathrm{MPa}$ - for the addition of $0.1 \% \mathrm{~W}$ and Mo, whereas, in the silumins with the $\mathrm{W}$ and Mo addition, a slight decrease of hardness HB was stated.

\section{Acknowledgements}

The project was financed from the means of the National Centre for Research and Development in years 2013 - 2015 as project UDAPOIG.01.04.00-10-079/12.

\section{References}

[1] Piątkowski, J. (2013). Influence of overheating temperature on the shape of primary silicon crystals in hypereutectic AlSi cast alloy. Solid State Phenomena. 203-204, 417-422.

[2] Piątkowski, J. \& Gajdzik, B. (2013). Testing phase changes in Al-Si cast alloys with application of thermal analysis and differential calorimetric analysis. Metallurgy. 52(4), 469472.

[3] Piątkowski, J. \& Jabłońska, M. (2014). Analysis of material reliability of AlSi17Cu5 alloy using statistical Weibull distribution. Metallurgy. 53(4), 617-620.

[4] Binczyk, F. \& Piątkowski, J. (2003). Crystallization of the silumin AlSil7 with the addition of $\mathrm{Cr}$, Co and Ti. Archives of Foundry Engineering. 3(9), 39-44. (in Polish).

[5] Sahoo, K.L. \& Pathak, B.N. (2009). Solidification behaviour, microstructure and mechanical properties of high Fecontaining $\mathrm{Al}-\mathrm{Si}-\mathrm{V}$ alloys. Journal of Materials Processing Technology. 209, 798-804.

[6] Sahoo, K.L., Das, S.K. \& Murty, B.S. (2003). Formation of novel microstructures in conventionally cast Al-Fe-V-Si alloys. Materials Science and Engineering. 355(1-2), 193200.

[7] Alloy Phase Diagrams. ASM Handbook Vol. 3. 1992.

[8] Okamoto, H. (2010). Al-Mo (Aluminum-Molybdenum). Journal of Phase Equilibria and Diffusion. 31(5), 492-493.

[9] Pietrowski, S., Pisarek, B., Władysiak, R., Gumienny, G. \& Szymczak, T. (2009). TDA curves of metals alloys and the control of their quality. In Szajnar, J. Progress of the Theory and Practice Foundry, (pp. 345-377), Katowice Gliwice: PAN.

[10] Pisarek, B.P. (2013). Model of Cu-Al-Fe-Ni Bronze Crystalization. Archives of Foundry Engineering. 13(3), 7279.

[11] Rapiejko, C., Pisarek, B., Czekaj, E. \& Pacyniak, T. (2014). Analysis of the Crystallization of AZ91 Alloy by Thermal and Derivative Analysis Method Intensively Cooled in Ceramic Shell. Archives of Foundry Engineering. 14(1), 97102.

[12] Kacprzyk, B., Szymczak, T., Gumienny, G. \& Klimek, L. (2013). Effect of the Remelting on Transformations in CoCr-Mo Prosthetics Alloy. Archives of Foundry Engineering. 13(3), 47-50.

[13] PN-EN 1706:2011. Aluminum and aluminum alloys. Castings. The chemical composition and mechanical properties. (in Polish). 